DOI: 10.2478/linpo-2018-0014

\title{
Reflexes of Proto-Ryukyuan * $i$ and *u in Miyakoan as a chain shift
}

\author{
Aleksandra Jarosz \\ Nicolaus Copernicus University in Toruń \\ aljarosz@umk.pl
}

\begin{abstract}
Aleksandra Jarosz. Reflexes of Proto-Ryukyuan *i and $*^{*}$ in Miyakoan as a chain shift. The Poznań Society for the Advancement of Arts and Sciences, PL ISSN 0079-4740, pp. 99-121

The paper examines conditioned changes that occurred in Miyakoan (mostly Proto-Miyakoan) reflexes of Proto-Ryukyuan close vowels $*_{\mathrm{i}}$ and $*_{\mathrm{u}}$ after the unconditioned raising of Proto-Ryukyuan $*_{\mathrm{e}}$ and $*_{\mathrm{o}}$ had taken place. These changes in close vowels are interpreted here as chain shifts. The core assumption is that changes in $*_{i}$ and $*_{u}$ occurred in response to the raising of $*_{\mathrm{e}}$ and $*_{\mathrm{o}}$ in order to avoid or compensate for the functionally damaging merger of $* \mathrm{i} / *_{\mathrm{e}}$ and $* \mathrm{u} / *_{\mathrm{o}}$.

The paper shows that there is a rather wide range of conditions under which $*_{i}$ and $*^{*}$ produced distinct reflexes in Miyakoan. Consequently, these vowels acted differently after stops, after sibilants, after nasals, in an onsetless/standalone position, after the flap, before the flap, and before nasals and other sonorants word-initially. At the same time, reflexes of both proto-vowels have been observed to maintain certain symmetry, meaning that in a similar environment, $*_{\mathrm{i}}$ and $*_{\mathrm{u}}$ generally underwent similar or analogical changes.

Thus, the conditions for identifying Miyakoan reflexes or $*_{i}$ and $*_{u}^{u}$ are listed and specified in this paper. Conversely, it is argued that unless one of these conditions has been met, one should reconstruct a Proto-Ryukyuan mid-vowel rather than a close vowel. Such specification may influence the comparative study of Ryukyuan languages to a significant degree, challenging a number of the so far established reconstructions (most notably Thorpe 1983).
\end{abstract}

Keywords: Japonic, Ryukyuan, Sakishima, Miyakoan, proto-language, comparative linguistics, chain shift

\section{Foreword}

Mid-vowel raising is an unconditioned, regular change that took place in most Ryukyuan "regiolect" as opposed to most regiolects of mainland Japanese. This can be observed in such pairs of cognates as RK $t i$ : vs. JP te 'hand', or RK sudi vs. JP sode 'sleeve'.

Thorpe 1983: 32 and Vovin 2010: 33-34 reconstruct for Proto-Ryukyuan a five-vowel system with both mid-vowels present, implying that the raising was an independent innovation that took place later in the respective Ryukyuan languages/language subgroups. The occurrence of the raising only after the split took place is also implied by written 
records such as the kana-syllabary written Omorosōshi song compilation from 16th-17th century, which represents Northern Ryukyuan varieties with a primary focus on Shuri-Okinawan. Inconsistent use of either mid- or close vowel syllabographemes in lexical items whose Japanese cognates have mid-vowels suggest that at the time of the compilation of Omorosōshi, mid-vowel raising in Shuri was on the way, but not yet completed (Takahashi 1991: 4-5; Nakama 1992: 76-66; Nishioka 2013: 76-77).

The distinction of PR mid- and close vowels was one heavily loaded functionally. It contributed to a number of minimal pairs such as *pune 'boat' $\neq$ *pone 'bone', *ki 'fog' $\neq *$ ke 'tree', *ni 'boiling' $\neq *$ ne 'root', or *uke 'receiving' $\neq *$ oke 'rising'. Once the distinction was leveled in daughter languages, the ensuing homophony would have been damaging to the functionality of the system. This author's hypothesis is that in order to prevent such homophony, Ryukyuan languages employed compensatory strategies which can be identified as examples of a chain shift.

By a chain shift is understood here what Hock 1991: 156 defines as "developments [...] in which one change within a given phonological system gives rise to other, related changes". The subtype of chain shift called a push chain will be of particular interest here. ${ }^{1}$ Campbell 1998: 45 explains the concept of a push chain in the following way.

Behind a push chain is a notion that languages (or their speakers) want to maintain differences between sounds in the system in order to facilitate understanding, the processing of what is heard. If a sound starts changing by moving into the articulatory space of another sound, in the push-chain view, this can precipitate a change where the sound moves away from the encroaching one in order to maintain distinctions important to meaning. If the fleeing sound is pushed towards the articulatory space of some other sound, then it too may shift to avoid the encroachment, thus setting off a chain reaction called the push chain.

In this paper it will be argued that what accomapnied the raising of mid-vowels in Ryukyuan vernaculars was a kind of a chain shift, although understood in a broad way, the unit of chain shifting being sound sequences rather than single sounds. According to the view adopted in this paper, a chain shift may potentially affect not only the specific segment which is on the way to undergo a merger with another phoneme, but also a neighboring segment, such as a syllable onset in the case when the nucleus is about to be raised. In other words, the loss of an original distinction, in this case between PR $*_{\mathrm{e}} / *_{\mathrm{i}}$ and $*_{\mathrm{o}} / *_{\mathrm{u}}$, may lead to changes in adjacent sounds that will compensate for the merger.

Generally speaking, when Ryukyuan *e and *o had begun to shift toward *i and *u, the affected daughter languages applied a range of conditioned changes to the affected environments in order to maintain and/or facilitate their disambiguation. This topic has been broadly covered in Ryukyuan linguistics, drawing authors' attention since the early

${ }^{1}$ One needs to emphasize the solely theoretical nature of the push-chain related ideas presented in this paper, as Hock 1991: 157 points out that the concept itself lacks convincing empirical support and is as such "controversial". Martinet 1952: 11 also observes that "in practice, it may often be difficult to tell whether we have to do with a $[\ldots]$ drag-chain, or a $[\ldots]$ push-chain". 
days of academic Ryukyuan studies, as evidenced among others by the 1934 papers of Iha \& Hashimoto, Iwakura, and Nakasone in journal Hoggen (cf. References), in which the respective authors remark how consonant oppositions such as palatalized/non-palatalized or glottalized/aspirated have taken over the distinction between close and mid vowels attested in Japanese. A discussion of how changes in the vocal system influenced Ryukyuan consonants lies at the core of such works as Nakamoto 1976 (cf. especially the discussion on pp. 122-184) or Nakama 1992: 62-81. ${ }^{2}$ Expanding on this tradition, this paper will offer a close-up at such changes which took place in Miyakoan, a language from the Southern Ryukyuan (Sakishima) group which has been found to be rather consistent and innovative in keeping the distinction of PR close and mid-vowels.

This paper's definition of chain shifts includes small, two-stage chain shifts, such as when a proto-vowel only changes some of its features in order to avoid a merger without directly causing more changes elsewhere in the vowel system. This is what Labov 1994: 118-119 calls a "minimal chain shift", as opposed to a longer "extended chain shift".

Lastly, a disclaimer needs to be made that this paper focuses on presenting the data, without delving too much into theoretical dispute on the cause and chronology of the changes in question. Hypotheses concerning the theoretical aspects of this study will be thus saved for another occasion.

\section{Methodology, sources and editorial conventions}

For analyzing the sound changes from PR to Miyakoan, this author's own reconstructions of an earlier, unified stage of Miyakoan - that is, Proto-Miyakoan - have been used. Proto-Miyakoan is defined here as the language that came to existence after the split of Proto-Sakishima into the respective ancestors of Miyakoan and Macro-Yaeyaman ${ }^{3}$ (Proto-Macro-Yaeyaman) and which had been spoken before it further diversified into the regional varieties of the Miyako islands vernacular as we know it today.

The relationship among the proto-languages of interest has been illustrated in Figure 1 below. Entities constituting direct ancestors of Miyakoan have been boldfaced.

The reconstructed inventory of PM used in this study consists of over 500 lexical items. In essence, the reconstructions were based on two rich dialectological lists covering four and five Miyakoan regiolects each, Hirayama 1967 and Nakasone et al. 1968, with a greater focus on the former. These reconstructions have been supplemented with findings from Nikolay Nevskiy's 1920s fieldwork lexical notes referred to in Japan as Miyako hōgen nōto, henceforth MHN (Nevskiy 2005, transcribed in Jarosz 2015), with a great Irabu regiolect dictionary Tomihama 2013, and with a modern multi-region lexical list in Kibe 2012.

\footnotetext{
${ }^{2}$ I would like to thank an anonymous reviewer of the first version of the draft who suggested the existing literature which approaches sound changes in Ryukyuan from the chain-shift angle.

3 This classification follows Figure 1 in Pellard 2015: 15.
} 


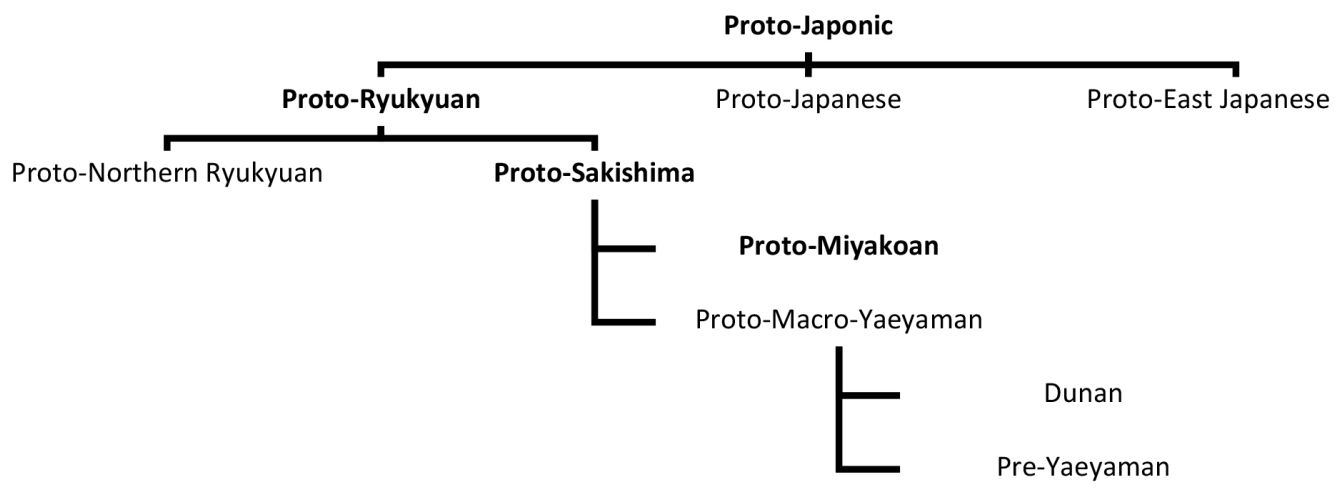

Figure 1. Genetic relationship of Japonic proto-languages (after Pellard 2015)

The sources in question have been selected as a blend of advantages associated with age, amount, variety and accuracy. MHN is the oldest source and as such it represents Miyakoan at a stage relatively unaltered by the impending standard Japanese domination. ${ }^{4}$ It also employs a precise phonetic notation. It focuses, however, mostly on Hirara and/ or Sawada regiolects, and the equivalents of the recorded items in different regiolects are given on an inconsistent basis, which limits the applicability of MHN in the reconstruction of PM. By contrast, Kibe 2012 records a limited vocabulary list (slightly above 300 items), but provides data from at least nine regions in an exquisitely detailed notation. Nevertheless, the advantage of its recent release year and the consequent fact that it was able to apply modern linguistic methodologies and frameworks is countered by the reality that the Miyakoan recorded there had been in the stage of endangerment-related atrophy for a number of decades, which fact is reflected in that for many items even in those basic vocabulary lists the speakers either could not give any Miyakoan form or gave an obvious Japanese loan. Thus, MHN and Kibe 2012 are thought to usefully balance each other in moderating what gaps and inaccuracies may be found in Hirayama 1967 and/or Nakasone et al. 1968. These four sources are further supported by the evidence found in the following lexicographic publications: Tomihama 2013, which provides an abundance (over 17,000 entry words) of lexical material from a single regiolect, Irabu-Nakachi, in general not covered elsewhere; Shimoji 2017, a basic dictionary of the Tarama regiolect; and Shimoji 1979, a relatively small but informative source centered on the Hirara regiolect.

All sources in question use a more or less narrow phonetic transcription, at times indicating slightly discrepant forms for the same lexical items. For the purpose of the PM reconstruction, vocabulary items of interest have been uniformly retranscribed phonologically based on the phonological inventories in Jarosz 2015: 178-222.

${ }^{4}$ This advantage of MHN is obvious even when comparing it to the next oldest source, Hirayama et al 1967: where the latter gives items which are clearly modern loans from Japanese, such as wata 'cotton' or Sino-Japanese loans for numerals above '20', MHN presents bata and Japonic numerals respectively. One can be more confident in assuming that this kind of vocabulary represents the inherited Miyakoan lexicon. 
The proposed PM phoneme inventory is presented in Tables 1 and 2..$^{5}$ Length distinction is relevant for both vowels and consonants.

Table 1: PM vowel chart

\begin{tabular}{l|c|c|c}
\hline & Apical & Front & Back \\
\hline Close & 1 & $\mathrm{i}$ & $\mathrm{u}$ \\
\hline Open & \multicolumn{3}{|c}{$\mathrm{a}$} \\
\hline
\end{tabular}

Table 2: PM consonant chart

\begin{tabular}{l|c|c|c|c|c|c}
\hline & Bilabial & Labio-dental & Alveolar & $\begin{array}{c}\text { Alveolo- } \\
\text { palatal }\end{array}$ & Palatal & Velar \\
\hline Stop & $\mathrm{p}, \mathrm{b}$ & & $\mathrm{t}, \mathrm{d}$ & & & $\mathrm{k}, \mathrm{g}$ \\
\hline Fricative & & $\mathrm{f}, \mathrm{v} \sim \mathrm{v}$ & $\mathrm{s}$ & 6 & & \\
\hline Affricate & & & $\mathrm{ts}, \mathrm{dz}$ & $\mathrm{tc}^{6}$ & & \\
\hline Nasal & $\mathrm{m}$ & & $\mathrm{n}$ & & & \\
\hline Flap & & & $\mathrm{r}$ & & & \\
\hline Glide & & & & & $\mathrm{j}$ & \\
\hline
\end{tabular}

Unless indicated otherwise, Proto-Ryukyuan reconstructions have been cited after the seminal Thorpe 1983 (mostly 259 ff). Items whose notation was discrepant with the notation applied in this paper (such as representing alveolo-palatal consonants as $<$ si $>$, $\langle\mathrm{zi}\rangle,\langle\mathrm{ci}\rangle$ rather than $\left.\left\langle_{6}\right\rangle, \mathrm{d}_{\mathrm{b}}\right\rangle, \mathrm{t}_{6}>$ ) have been adjusted to uniformly fit this paper's conventions. Where the pertinent PR reconstructions are lacking in Thorpe 1983, this author's tentative reconstructions derived from her own Proto-Sakishima reconstructions ${ }^{7}$ have been given.

On a number of occasions, non-existent or presumably incorrect forms have been presented. In order to avoid ambiguity with the asterisk mark indicating reconstructions, these incorrect forms have been preceded by a capital $<\mathrm{X}>$.

\footnotetext{
${ }^{5}$ Although this author has arrived at these inventories independently, they essentially match Proto-Miyakoan inventories presented in Pellard 2008: 298-327.

${ }^{6}$ As of now, the reconstruction of this consonant's voiced counterpart, /dz/, would be highly uncertain, and therefore it has been decided not to include it in the PM consonant inventory. In the reconstructed sample of PM vocabulary * $\mathrm{d} z$ is considered as a possibility in two items (and their derivates) only, *kadzi 'wind' and *gudzuv 'to tickle'. Bentley 2008 does not posit *z for PM and for 'wind' he reconstructs *kaze (ibid., 299), which matches this author's tentative Proto-Sakishima reconstruction of this lexeme.

${ }^{7}$ Again, these reconstructions have been based on the Hirayama et al. 1967 lexicon and supplemented mostly with the data from Miyara 1980 and Ikema 2003 for the Yaeyama and Yonaguni vocabulary.
} 
Miyakoan finite verb forms in general correspond to infinitive forms (ren'yōkei in the traditional Japanese terminology) in other Ryukyuan languages or in Japanese. ${ }^{8}$ For this reason, the PR ancestor forms of Miyakoan verbs will be provided in the infinitive, the stem separated from the ending with a hyphen unless the infinitive form is homophonous with the stem.

Finally, discussing Proto-Miyakoan one cannot avoid mentioning the essential work Bentley 2008 devoted specifically to the reconstruction Proto-Sakishima and its three daughter languages. Although Bentley 2008 may be occasionally referred to in the present paper, it will not be relied on for reconstructions due to significant disagreements of its results with this author's views. Most importantly for this paper, Bentley assumes that the distinct reflexes of proto-vowels in contemporary Miyakoan lead to the immediate ancestor, which is PM, and consequently reconstructs for PM a five-vowel system with both mid-vowels present (Bentley 2008: 63). This author, however, maintains that since no known Miyakoan regiolect preserves inherited mid-vowels, and since the reflexes of PR mid-vowels are in all relevant instances identical in all known Miyakoan regiolects, it would be redundant to reconstruct a five-vowel system for PM and assume that all Miyakoan regiolects underwent the changes independently after the split of the proto-language. How exactly did reflexes of the PR close vowels come to be represented at the PM stage will precisely be the question answering to which this paper will attempt to undertake.

\section{Reflexes of Proto-Ryukyuan close vowels in specific environments}

Unless indicated otherwise, charts in subsections 3.1.-3.8. will represent the PM environment of the specific changes in the left column, and the reconstructed vocabulary evidence for the presented PR > PM evolution in the right column.

\subsection{PR *i after stops}

Following the PR stops ${ }^{*} \mathrm{p},{ }^{*} \mathrm{~b},{ }^{*} \mathrm{k},{ }^{*} \mathrm{~g}$, the reflex of $\mathrm{PR} *_{\mathrm{i}}$ became the peculiar Miyakoan vowel ${ }^{*}$, often referred to as the apical vowel by specialists in Miyakoan (for an in-depth discussion of articulatory characteristics of this sound, cf. Aoi \& Niinaga 2013). This change resulted in a two-stage push-chain differentiation of vowel phonemes:

$$
\mathrm{i}>\mathrm{l} / \mathrm{p}, \mathrm{b}, \mathrm{k}, \mathrm{g}
$$

${ }^{8}$ An apparent exception to this correspondence are the verbs with a vowel-final stem, which correspond to Japanese finite or shūshikei forms (Hirara ko: vs. JP kau 'to buy', Hirara $n u$ : vs. Japanese $n \bar{u}$ 'to sew'). Verbs from this group remain, however, outside the immediate interest of this paper. 
Table 4: PR *i after PM stops

\begin{tabular}{|c|c|}
\hline PM environment & Examples \\
\hline $\mathrm{p}_{-}$ & $\begin{array}{l}\text { PR *pito > PM *p1tu 'man’ } \\
\text { PR *pi > PM *p1: 'day' }\end{array}$ \\
\hline$b_{-}$ & $\begin{array}{l}\mathrm{PR} * \mathrm{tabi}^{9}>\mathrm{PM} * \text { tabl 'journey' } \\
\mathrm{PR} * \text { kabi }>\mathrm{PM} * \text { kabl 'paper' }\end{array}$ \\
\hline $\mathrm{k}_{-}$ & $\begin{array}{l}\mathrm{PR} * \text { toki }^{10}>\mathrm{PM} * \text { tuk } 1 \text { 'time' } \\
\mathrm{PR} * \text { kimo }>\text { PM *kmu 'liver' }\end{array}$ \\
\hline$g_{-}$ & $\begin{array}{l}\text { PR *kugi > PM *fugl 'nail' } \\
\text { PR *pagi > PM *pagl 'leg' }\end{array}$ \\
\hline
\end{tabular}

This *1 later followed different paths of development in different regions, depending on the degree of fricativization it caused. ${ }^{11}$ Vocabulary items in Kibe 2012 reveal that in most settlements of the Miyako main island as well as in Irabu, *1 came to be realized as $[\mathrm{s}] \sim\left[{ }^{\mathrm{s}} 1\right]$ after voiceless and as $[\mathrm{z}] \sim\left[{ }^{\mathrm{z}} \mathrm{l}\right]$ after voiced consonants, in which contexts they can be phonologically interpreted as /s/ and /z/ respectively (as they are in Jarosz 2015). A similar development can be observed for the regiolect of the Ōgami island (as recorded in Pellard 2008 and 2010). On the other hand, in places such as Ikema, Karimata, or Kuninaka on Irabu, *1 either lenited to a "regular" central vowel /i/ or, in the case of Ikema at least, reversed to the "regular" front close $/ \mathrm{i} / .^{12}$

Also, for reasons explained in Thorpe 1983: 63-66 and further discussed in 3.2. below, $\mathrm{PM} * \mathrm{t}$ and $* \mathrm{~d}$ did not co-occur with the reflex of PR $* \mathrm{i}$.

\section{2. $P R *_{i}$ after sibilants}

Following $\mathrm{PM} *_{\mathrm{s}}$, *ts and $*_{\mathrm{dz}}$, PR $*_{\mathrm{i}}$ uniformly changed into $*_{1}$, resulting in another two-stage push-chain:

$$
\mathrm{i}>\mathrm{l} / \mathrm{s}, \mathrm{ts}, \mathrm{dz}
$$

The differentiation of $\mathrm{PR} *_{\mathrm{i}}$ and $*_{\mathrm{e}}$ in this environment is distinct from the post-stop one discussed in 3.1. in the respect that it had largely been arrested at the PM stage.

9 Tentative reconstruction by the author; PS *tabi.

10 Tentative reconstruction by the author; PS *tuki.

11 Fricative characteristics of this vowel have also been reflected in the term fricative vowel, Japanese masatsu boin, used in Pellard \& Hayashi 2012, one of the papers in Kibe 2012.

12 One also needs to take account of the fact that in certain regiolect groups, such as Ikema or Irabu, PM velar stops underwent affricatization in the context in question: $* \mathrm{k}>\mathrm{ts}$ and $* \mathrm{~g}>\mathrm{dz}$, which automatically (cf. the discussion of $*_{\mathrm{ti}}>*_{\mathrm{ts}}$ in 3.2.) disabled the post-velar fricativization of $*_{1}$. This change can also be viewed as the counterpart of fricativization of ${ }^{*} 1$ in these regiolects; either way, the distinction between PR sequences such as *ki and *ke or *gi and *ge has still been maintained. 
That is to say that most of the reconstructed PM forms are identical to their present-day equivalents in specific regions.

According to reconstructions in Thorpe 1983: 66, the PM sequence *ts $(<\mathrm{ci}>$ in Thorpe's notation) evolved from PR *ti. This change is a consequence of PR *te becoming *ti in PM (such as *teda $>*$ tida 'sun'), and it can be viewed as a double differentiation effort expressed by changing the articulation of both the consonant and the vowel of the original $\mathrm{PR} * \mathrm{ti}$, in which case the order of changes would have been $\mathrm{PR} * \mathrm{ti}>$ PS *tsi $>$ PM *ts . Alternatively, the change in question may be also hypothesized to have been a secondary result of the vowel transformation which eased the articulation of the consonant in this specific environment, the order of changes being PR *ti $>$ PS $*$ ti $>*$ tsi $>$ PM *tsp.

Table 4: PR *i after PM sibilants

\begin{tabular}{|c|c|}
\hline PM environment & Example \\
\hline $\mathrm{s}_{-}$ & $\begin{array}{l}\mathrm{PR} * \mathrm{uci}^{13}>\mathrm{PM} * \text { *usl 'cow' } \\
\mathrm{PR} * \mathrm{cima}^{14}>\mathrm{PM} * \text { s } \\
\end{array}$ \\
\hline ts & $\begin{array}{l}\text { PR *kuti > PM *futsl 'mouth' } \\
\text { PR *miti > PM *mtsl 'road' }\end{array}$ \\
\hline $\mathrm{dz} z_{-}$ & $\begin{array}{l}\text { PR * pidzl > PM *pidzl 'elbow' } \\
\text { PR *todzi > PM *tudzl 'wife' }\end{array}$ \\
\hline
\end{tabular}

\section{3. $P R * u$ after stops}

In contrast to $\mathrm{PR} * \mathrm{i},{ }^{*} \mathrm{u}$ preceded by stops triggered a kind of change which primarily involved the preceding consonant rather than the vowel itself. What the consonants underwent was lenition, or fricativization, to be specific: voiceless stops lenited to $*$, and voiced lenited to $*_{\mathrm{v} \sim 0 .}{ }^{15}$

Importantly, however, the sequence *gu seems to have been rather rare in PR vocabulary, so PM vocabulary items with its clear reflexes are quite few - even more so if one excludes the instances that trigger FAR (discussed below in 3.7.).

${ }^{13}$ Tentative reconstruction by the author; PS *usi. The same PM reconstruction is found in Pellard 2009: 322.

${ }^{14}$ Tentative reconstruction by the author; PS *sima. The same PM reconstruction is found in Pellard 2009: 322.

15 Thorpe 1983: 62-63, 80, 84 does not recognize /f/ on the phonemic level in Sakishima regiolects, assigning the voiceless labio-dental realization to the phoneme $/ \mathrm{h} /$ instead. Consequently, he posits * $\mathrm{h}$, phonetically realized as $[\beta]$, as the voiced counterpart of this $* h$, and in his reconstructions, *hu represents roughly the same stage as *vu in the present study. 
Table 5: PR *u after PM stops

\begin{tabular}{l|l}
\hline \multicolumn{1}{c|}{ PM environment } & \multicolumn{1}{c}{ Examples } \\
\hline$*$ pu & PR *pune $>$ PM *funi 'boat' \\
\hline$* \mathrm{ku}$ & $\mathrm{PR} * \mathrm{kuti}>\mathrm{PM} *$ futs 'mouth' \\
\hline$* \mathrm{bu}$ & $\mathrm{PR} * \mathrm{pabu}>\mathrm{PM} *$ pavu 'snake' \\
& $\mathrm{PR} * \mathrm{kobu}>\mathrm{PM} * \mathrm{kuvu}$ 'spider' \\
\hline$* \mathrm{gu}$ & $\mathrm{PR} *$ daugu ${ }^{16}>\mathrm{PM} *$ dauvu 'tools' \\
& $\mathrm{PR} *$ kacigui $^{17}>\mathrm{PM} *$ kacivu 'phlegm' \\
\hline
\end{tabular}

After the split of PM, the vowel in *fu would further devoice, in certain words eventually getting deleted. ${ }^{18}$ In turn, *vu mostly dropped the vowel, retaining just the consonant. Alternatively, one can also interpret the ${ }^{*} v u$ reflexes in modern Miyakoan as a result of a further lenition of the original consonant to its eventual deletion, while the vowel assimilated some of the consonant's characteristics, becoming non-syllabic and unrounded. The latter interpretation is supported by evidence from regiolects which retained ${ }^{*} \mathrm{u}$ and not $* \mathrm{v}$, as in Tarama Tarama po:/pau for 'snake' - cf. Hirara pav, Uechi bav, Sarahama hav.

The development of ${ }^{*} \mathrm{pu},{ }^{*} \mathrm{ku}, * \mathrm{bu}$ and ${ }^{*} \mathrm{gu}$ until the post-PM stage can be therefore roughly summarized as follows:

$$
\begin{aligned}
& * \mathrm{pu}, * \mathrm{ku}>*_{\mathrm{fu}}>\mathrm{fu} \sim \mathrm{f} \\
& * \mathrm{bu}, * \mathrm{gu}>*_{\mathrm{vu}}>\mathrm{vu} \sim \mathrm{v} \sim \mathrm{u} .
\end{aligned}
$$

\section{4. $P R * u$ after sibilants}

After sibilants, *u displays characteristics identical to $* \mathrm{i}$, becoming PM * 1 . Consequently, in this environment, a merger of the PR $*_{i}$ and $*_{u}$ occurred at the PM stage.

$$
\mathrm{u}>\mathrm{l} / \mathrm{s}, \mathrm{ts}, \mathrm{dz}
$$

${ }_{16}$ An old Sino-Japanese loan, estimated as one old enough (Pellard 2015: 23; Pellard does not mention specifically this item, but it fits his description of the Early Middle Japanese loans into Ryukyuan) to attempt its PM reconstruction.

17 Tentative reconstruction by the author. The Miyakoan word for 'phlegm' has only been found in a small Hirara dictionary Shimoji 1979, but as its cognates have been confirmed for North Ryukyuan varieties such as Nakijin (kacigui, cf. Nakasone 1983) and Shuri (kasagwi:, cf. Kajiku \& Inafuku 1992), it should be enough to warrant a reconstruction on a Proto-Ryukyuan level.

${ }^{18}$ This is true at least for some Miyakoan regiolects; for instance, in Hirara, Karimata 2005: 86-87 claims there is no basis to postulate an $/ \mathrm{u} /$ phoneme in words such as $f m u$ (PR *kumo 'cloud') on the articulatory grounds. 
Table 6: PR *u after PM sibilants

\begin{tabular}{|c|c|}
\hline PM environment & Example \\
\hline $\mathrm{s}_{-}$ & $\begin{array}{l}\mathrm{PR} * \mathrm{usu}^{19}>\mathrm{PM} * \text { us } 1 \text { 'mortar' } \\
\mathrm{PR} * \mathrm{sumi}^{20}>\mathrm{PM} * \text { slm 'coal' }\end{array}$ \\
\hline ts & $\begin{array}{l}\mathrm{PR} * \text { tubo }^{21}>\mathrm{PM} * \text { tsp bu 'jar' } \\
\mathrm{PR} * \text { tume }>\mathrm{PM} * \text { tspmi 'nails, claws' }\end{array}$ \\
\hline $\mathrm{dz}_{-}$ & $\begin{array}{l}\mathrm{PR} * \mathrm{medzu}^{22}>\mathrm{PM} * \text { midzl 'water' } \\
\mathrm{PR} * \mathrm{kedzu}^{23}>\mathrm{PM} * \mathrm{kidz} 1 \text { 'wound' }\end{array}$ \\
\hline
\end{tabular}

In the form of his Rule 5, Thorpe 1983: 31 postulates that this is a change that began already in PR on a phonetic level: after PR *t, ${ }^{\mathrm{s}}$ and ${ }^{*} \mathrm{z}, *_{\mathrm{u}}$ was realized as unrounded [u], which later carried on into a large number of daughter languages as vowel phonemes distinct from *u. As a consequence, in some of these daughter languages, like in Miyakoan, $*_{\mathrm{i}}$ and $*_{\mathrm{u}}$ became neutralized in the post-sibilant position (Thorpe 1983: 32).

\section{5. $P R * i$ and $* u$ after nasals}

In general, close vowels which followed PM *m or *n were dropped. This correspondence of $\mathrm{PR} * \mathrm{i}$ and $*_{\mathrm{u}}$ with zero in Miyakoan has not been recognized in the PR vowel correspondences table in Thorpe 1983: 32; it is, however, discussed in ibid., 93-94 as a frequent occurrence in Ryukyuan daughter languages, with Miyakoan claimed as "most prone to this development".

Thorpe (ibid.) also claims that the post-nasal close vowels are "almost invariably preserved before *s". From observations of Miyakoan it appears to be true concerning the following sequences: *mus, *nus, *nis. There is, however, a number of instances in which *mis > *ms: *miso $>$ *msu 'soya bean curd', *misa 'good'> song language msaz 'a skillful fisherman'. ${ }^{24}$ The reason why the original close vowels following a nasal were more stable in the $*_{n} \_s$ rather than $*_{m} \_s$ environment could be because $* n$ shared the same place of articulation as the following *s consonant. One can assume that due to this factor, the articulation of a consonant cluster such as /ns/ would have been more difficult than $/ \mathrm{ms} /$, and as a consequence, the original vowels were retained. They were not preserved, however, across morpheme boundaries: cf. Hirara $n n$ 'to be alike', but $n n-s a$ 'being alike'.

19 Tentative reconstruction by the author, PS *usi. The same PM reconstruction is found in Pellard 2009: 354 .

${ }^{20}$ Tentative reconstruction by the author, PS *simi.

${ }^{21}$ Tentative reconstruction by the author, PS *tsibo. The same PM reconstruction is found in Pellard 2009: 345.

${ }^{22}$ Reconstruction from Vovin 2010: 198 has *medu, hinting at a possibility not to reconstruct ${ }^{*} \mathrm{z}$ on the PR level. The same PM reconstruction is found in Pellard 2009: 302.

${ }^{23}$ Reconstruction by Vovin 2010: 40.

${ }^{24}$ Reconstructions based on the correspondences suggested in MHN. There are also other (Northern) Ryukyuan forms corresponding to $m s u$ which display the infrequent in Miyakoan /ns/ consonant sequence. 
Other exceptions to the discussed vowel-drop correspondences can perhaps be explained lexically. For instance, the PM stem for 'three', *mi: (PR *mi), possibly retained the vowel in order to avoid homophony with the stem meaning 'six', *mm $\left(\mathrm{PR} * \mathrm{mu}^{25}\right)$. This could also imply at a relative order of changes according to which first *u and only then $*_{i}$ were dropped in these environments, which fact is underscored by a general theory that in Ryukyuan vowel raising the back mid-vowel had begun to rise earlier than the front (cf. Nakamoto 1976).

One can also attempt to explain different exceptions with a hypothesis that the vowel would be preserved if it had been long or a part of a diphthong on the PR level, as in a tentative PR *mei ${ }^{26}>\mathrm{PM} * \mathrm{mi}$ 'flesh'. The matter remains open for further consideration accompanying the higher-level reconstructions.

Table 7: PR close vowels after nasals

\begin{tabular}{|c|c|}
\hline PR environment & Examples \\
\hline *mi & $\begin{array}{l}\mathrm{PR} * \mathrm{kami}^{27}>\mathrm{PM} * \mathrm{kam} \text { 'god' } \\
\mathrm{PR} * \mathrm{ami}^{28}>\mathrm{PM} * \text { am 'net' } \\
\mathrm{PR} * \text { mita }>\text { PM *mta 'earth, soil' }\end{array}$ \\
\hline *mu & $\begin{array}{l}\text { PR *mune > PM *mni 'chest' } \\
\text { PR *mu > PM *mm 'six' }\end{array}$ \\
\hline$*$ ni & $\begin{array}{l}\text { PR *niga }>\text { PM *ngja 'bitter' } \\
\text { PR *ni- }{ }^{29}>\text { PM *nn 'to resemble' }\end{array}$ \\
\hline$*_{\text {nu }}$ & $\begin{array}{l}\mathrm{PR} * \text { enu }^{30}>\mathrm{PM} * \text { in 'dog' } \\
\mathrm{PR} * \text { nug-i }>\text { PM *ng| 'to undress' }\end{array}$ \\
\hline
\end{tabular}

The sequence of consonants resulting from this post-nasal vowel deletion may have further developed region-specifically through a partial assimilation of the nasal with the

${ }_{25}$ Both numeral reconstructions by the author. Unlike Thorpe, I am hesitant to reconstruct PR *mu:, because a long vowel would probably have been preserved in Miyakoan.

${ }^{26}$ An ad hoc reconstruction by the author. While Thorpe reconstructs the item in question as PR *mi (which indeed in all the cited North Ryukyuan regiolects has been inherited as mi:), Bentley 2008: 272 reconstructs the PS item as *məWi, apparently in order to account for all the Sakishima daughter language reflexes (which are not as straightforward). Alternatively, Pellard 2009: 304 reconstructs PM *m 11 for this item.

27 Tentative reconstruction by the author, PS *kami. The same PM reconstruction is found in Pellard 2009: 352.

28 Tentative reconstruction by the author, PS *ami.

29 Tentative reconstruction by the author, PS *ni-.

${ }^{30}$ Reconstruction by the author. Although both Thorpe (1983: 279) and Vovin (2010: 33) reconstruct *inu, the possibility that this initial $*_{\mathrm{i}}$ reflects $\mathrm{PR} * \mathrm{e}$ should be entertained in order to account for the regressive nasal assimilation phenomenon discussed in 3.8. If the proto-form had indeed been *inu, Miyakoan should have produced Xnn rather than in. Cf. also the Classical Japanese form wenu meaning 'dog' or 'puppy', although here a direct Miyakoan counterpart would have been Xbinu. Also, Bentley 2008: 255 reconstructs PS *enu. 
neighboring consonant. Hence PM *mts 1 and *mta > Ikema ntsך 'road', nta 'earth, soil' (remaining as $m t s\rceil$ and $m t a$ elsewhere); PM *mni > Yonaha $m n i$, but Kurima and Tarama $n n i$ and Hirara, Sawda, Ikema, Ōgami mmi 'chest'.

Furthermore, word-initial close vowels followed by nasals have also been assimilated. This is an example of what is referred to here as regressive nasal assimilation, and will be discussed in 3.8. below.

\section{6. $P R *_{i}$ and *u in onsetless syllables and after *j}

When appearing in an onsetless syllable (below also referred to as the "standalone position"), PR *i is reflected as *1, except when followed by a coronal consonant, and $\mathrm{PR} * \mathrm{u}$ mostly remained $* \mathrm{u}^{31}$ (except for sequences corresponding with Japanese /uwa/,

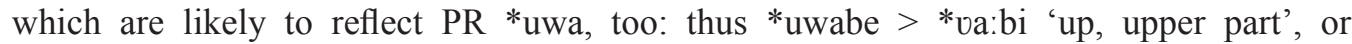
*uwaer-i > *vai 'to be chased after').

$*_{\mathrm{i}}$ followed by a voiced coronal consonant has mostly been retained as $/ \mathrm{i} /$, with the exception of Tarama, where there are instances such as PR *ider-i $>$ ndil 'to go out'. ${ }^{32}$ This change of $* \mathrm{i}[+$ coronal, +voiced] $>\mathrm{n}$ is also observed in other Miyakoan regiolects in interrogative words such as $n d z a$ 'where' or $n d z a$ 'which'. There have also been found putative instances of a similar change occurring in the environments with voiced obstruents with other places of articulation: PR *ige 'thorn'33 $>$ *ngi 'Pandanus tectorius tree', PS *inago ${ }^{34}>*$ mnagu 'sand'. Since these sound sequences do not occur very frequently in PR, a further investigation is necessary in order to account for the regularity of this type of sound change in Miyakoan.

The reflexes in Table 8 do not include contexts discussed in 3.7. and 3.8. as the flap rules and regressive assimilation.

${ }^{31}$ In the specific Miyakoan regiolects, standalone PM *u has become $/ \mathrm{v} /$ at least in certain settings, such as before coronals (Hirara $v t s 7$ 'inside', $v d a$ 'thick' vs. Sawada $u t s 7$, Sarahama $u d a$ respectively). Throughout MHN, especially in the Hirara lexicon, an tendency can be observed especially for the initial /u/ to be recorded as $/ \mathrm{v} /$, also with words which were clearly recent Japanese loans and not inherited vocabulary, such as vts7 'to copy' (Japanese utsusu), a fact which can, however, be explained as representing a Miyakoan approximation of the Japanese unrounded, slightly centralized realization of the back close vowel, [u].

It is, therefore, possible to hypothesize that this Miyakoan $/ \mathrm{v} /$ generally is a reflex of PS $* \mathrm{u}$ and should be regarded in opposition to $/ \mathrm{u} /$ as a reflex of PS $*_{0}$. Consequently, this would necessitate positing two different reflexes of these phonemes on the PM level, too, rather than a unified *u as tentatively proposed in this paper. A separate paper has been planned for an in-depth study of this hypothesis; here, I will just limit myself to indicating a number of vocabulary items which have possibly retained the differentiation of PS *u/*o: $v d a$ 'thick' vs. udi 'arm', vtas $\rceil$ 'to cause to hit' vs. utas 7 'to drop $\sim$ to cause to fall', vzlmiz 'to bury' vs. uzүmusך 'maggot' (examples from Irabu-Nakachi).

Should this hypothesis be proven, these changes of PS $*_{0}$ and $* u$ would become another illustration of push chains at work in PM.

${ }^{32}$ According to the data in Shimoji 2017, Tarama verbs ndil 'to go out' and ndasi 'to take out' also retain the conservative allomorphs idil and idasi.

${ }^{33}$ This word is reconstructed in Thorpe 1983 as *nige, i.e. with an initial nasal and not a standalone $*$ i. This author's reconstruction has been motivated by the mainland Japanese cognates indicated by Nevskiy, such as Saga and Higo (= Kumamoto) ige.

${ }^{34}$ This word is reconstructed in Bentley 2008 as *mVnago with an unspecified vowel. 
Table 8: PR close vowels in standalone positions

\begin{tabular}{l|l}
\hline \multicolumn{1}{c|}{ PR correspondence } & \multicolumn{1}{c}{ Example } \\
\hline$* \mathrm{Vi}$ & $\begin{array}{l}\mathrm{PR} * \mathrm{nawi}^{35}>\mathrm{PM} * \text { na) 'earthquake' } \\
\mathrm{PR} * \text { pai }>\mathrm{PM} *(\mathrm{kara}) \text { pa } 1 \text { 'ash' }\end{array}$ \\
\hline$* \# \mathrm{i}$ & $\mathrm{PR} *$ ibera $^{36}>\mathrm{PM} *$ bira 'rice scoop' \\
\hline$* \mathrm{Vu}^{37}$ & $\mathrm{PR} * \mathrm{bau}^{38}>\mathrm{PM} *$ bau 'stick' \\
\hline$* \# \mathrm{u}$ & $\mathrm{PR} * \mathrm{usu}^{39}>\mathrm{PM} *$ us 'mortar' \\
& $\mathrm{PR} *$ oker-i $>$ PM *oki 'to get up' \\
\hline
\end{tabular}

Any further development of the standalone ${ }^{*} 1$ has been, like the post-stop one (3.1.), region-specific: many Miyako main island regiolects have a moraic /z/, Tarama, Kurima, and Irabu island varieties from Sawada and Kuninaka have /1/ (usually identified as retroflex lateral approximant), while Ikema again has a "reversed" /i/, Oura retains / $/$, and Ōgami has /u/ (Pellard 2009, 2010).

As for $* \mathrm{j}$, from what has been so far concluded, it does not seem to have ever preceded PM *1 and, for that matter, also *i. Regarding *u, given Thorpe's reconstructions, sequences of $* \mathrm{j}$ with back vowels on the PR level are controversial: Thorpe refrains from reconstructing $\mathrm{PR} * \mathrm{ju}$ and/or *jo, and instead settles for neutralizing the vowel as an underspecified back vowel, therefore *jUnu 'the same', *jU 'night', *jUda 'branch', etc. In all these words, PM (and contemporary Miyakoan regiolects) has *ju, but, obviously, without the PR reconstructions one cannot decide if $\mathrm{PM} * \mathrm{ju}=\mathrm{PR} * \mathrm{ju}$ or $\mathrm{PR} * \mathrm{jo}$, or both. ${ }^{40}$ Whichever the case, it is clear that if PR had indeed differentiated between *ju and $*$ jo, their straightforward merger had been completed by the PM stage, implying that this might been one of the first contexts to be subjected to the back vowel rising.

35 Tentative reconstruction by the author, PS *nawi.

36 Tentative reconstruction by the author.

${ }^{37}$ In reality, this PR environment only rarely is still reflected as *Vu in PM, and it actually could be represented as $*_{\mathrm{au}}$ instead. This is because if the preceding PR vowel was *e, in PM it would be palatalized (Thorpe's *keU > PM *kju: 'today'), and if it had been *o, the two vowels would have merged into *u: after the raising of $*_{\mathrm{O}}$ (no convincing PR ancestor forms, however, have been found so far for the *ou environment).

38 Again, this is a Sino-Japanese loan old enough to be reconstructed for PR. This particular reconstruction is by Pellard 2015: 23 .

39 Tentative reconstruction by the author, PS *usi.

${ }^{40}$ A single item from MHN, Hirara zsa/z:sa 'mute', implies that perhaps PR *ju > PM *1. For this item, Nevskiy gives Northern Ryukyuan cognates (apparently citing them from Tōsō Miyara's 1926 Saihō Nantō Goikō vocabulary lists, i.e. Miyara 1980; cf. Jarosz 2015: 119-122) such as ju:sa (Kikai), Pju:sa (Nakijin), and Pju:ca (Amami Ōshima). While one cannot jump to the conclusions based on just a single correspondence, if the comparison does turn out valid, it would mean that PR *ju $=\mathrm{PM} *$, therefore PM *ju would have to be derived from $\mathrm{PR} * \mathrm{jo}$, disambiguating Thorpe's *jU reconstructions as *jonu 'the same' (which given the correspondence with Miyakoan should rather be *jono), *jo 'night', *joda 'branch', etc. 


\subsection{Flap instability}

The behavior of *r around close vowels in Ryukyuan is usually characterized by its deletion or other changes on the phonological level (these can be overviewed in tables in Thorpe's 1983: 98, 100). In Miyakoan, this has taken the shape of two diachronic rules earlier described in Jarosz 2015: 223-224 as the flap deletion rule (FDR) and flap assimilation rule (FAR).

Flap assimilation (FA) occurs in a part of the PR environments in which $*_{r}$ was preceded by $*_{\mathrm{i}}$ or $*_{\mathrm{u}}^{\mathrm{u}}$, and namely in the sequences which can be symbolically represented as OIr, whereby $\mathrm{O}$ stands for any obstruent and I for any close vowel $\left(* \mathrm{i}\right.$ or $*^{*} \mathrm{u}$ in the PR terms and ${ }^{*} 1$ or ${ }^{*} \mathrm{u}$ in the PM terms). The titular assimilation pertains to the flap being regressively and, in most contexts, completely assimilated with the preceding consonant, which change follows or accompanies the weakening and subsequent deletion of the original close vowel. This process can be illustrated in the following stages, beginning with the original PR form and ending with the final PM item:

$$
\begin{aligned}
& \text { PR *abura > PS *abura > PM *avụra }>\text { *avra }>\text { *avva 'grease, fat' } \\
& \text { PR *uciro > PS *ușiro }>\text { *usisso > PM *uş̨su }>\text { *ussu 'rear, behind'. }
\end{aligned}
$$

In reality, FA appears to have been limited to different environments for PR $*_{\mathrm{i}}$ and $* u$. For FA with complete assimilation ${ }^{41}$ to occur on the PM level, *1 needed to be preceded by a sibilant $\left({ }^{*},{ }^{*} \mathrm{~s},{ }^{*} \mathrm{dz}\right.$ in PR terms, ${ }^{*} \mathrm{~s},{ }^{*} \mathrm{ts},{ }^{*} \mathrm{dz}$ in PM terms), which practically narrows down the affected PM sequences to *spr, *tspr and *dzpr. The FAR conditions for $\mathrm{PR} * \mathrm{u}$, apart from also involving the post-sibilant contexts (in which a merger of $\mathrm{PR} *_{\mathrm{i}}$ and $*_{\mathrm{u}}$ occurred, cf. 3.4.), included the post-stop positions identical with those discussed in 3.3., that is *pur, *bur, *kur and * gur ${ }^{42}$. In practice, however, *pur and ${ }^{*}$ gur ${ }^{43}$ sequences are extremely rare in PR, especially outside the realm of verbs, and

${ }^{41}$ If one expands the definition of FAR so that it involves a spirantization of the *r, it would be observed in settings such as PS *piroma $>$ *pisoma $>$ PM *p plsuma 'daytime', or PS *kiri $>$ *kisi $>$ PM *kาs 'to cut'. In these instances, however, if anything triggered some kind of assimilation, it was the preceding vowel rather than the leftmost consonant.

${ }^{42}$ Bentley 2008: $49 \mathrm{ff}$. appears to be an attempt to partially explain FAR (without, however, calling it a rule or giving it a name). There is the reservation that Bentley's formula is VCV, in which V stands for a close vowel and $\mathrm{C}$ for voiced obstruent. As is clear from the evidence presented in this paper, these conditions are neither necessary (the first vowel is not relevant) nor sufficient (the change also involves voiceless obstruents, and the activation of FAR, as explained above, depends on a specific combination of the consonant and vowel preceding the flap). Elsewhere (2008: 54), when discussing one of the FA conditions (the underlying PM *spr), Bentley claims that the evidence of the flap loss "is not well-preserved in Miyako", for which reason he has "simply posited a vowel and left the assimilated spirant" in his reconstructions. As shown by the data introduced in Table 9, however, it is not exactly the case that the evidence for FA involving * 1 is scarce.

${ }^{43}$ An apparent example of non-verbal *gur reconstructed in Thorpe 1983: 48 as *puguri 'male sex organs' might be questionable as it does not produce a matching Miyakoan correspondence - PM *fugul and not Xfuvv?. Considering that chronologically FA precedes FD, the flap of Xpuguri would have been assimilated before it could be deleted. An expected ancestor form of Miyakoan *fugu should thus be *pugori. 
even more importantly, no actual instances of *pur reflexes undergoing FA have so far been found. ${ }^{44}$

Table 9: FAR contexts and examples

\begin{tabular}{|c|c|}
\hline Underlying PM segment & Example \\
\hline$*_{\text {vur }}(<\mathrm{PR} *$ bur $\sim$ gur $)$ & $\begin{array}{l}\mathrm{PR} * \text { abura }>\text { PM *avva 'oil' } \\
\mathrm{PR} * \text { tagur-i }{ }^{45}>\text { PM *tavv1 'to reel, to fold up' }\end{array}$ \\
\hline$*$ fur $(<\mathrm{PR} *$ kur $)$ & PR *kuro > PM *ffu 'black' \\
\hline$*_{\text {spr }}(<\mathrm{PR}$ *6ir $\sim$ sur $)$ & $\begin{array}{l}\text { PR *6irami > PM *ssam 'louse' } \\
\text { PR *sur-i > PM *ss1 'to rub' }\end{array}$ \\
\hline$* \operatorname{ts} \mathrm{r}\left(<\mathrm{PR} * \operatorname{tur}^{46}\right)$ & PR *katura ${ }^{47}>$ PM *katşra $>*$ kattsa 'vine' \\
\hline$*$ dzir $(<$ PR $*$ dzir $\sim *$ dzur $)$ & $\begin{array}{l}\text { PR *Gudzira }{ }^{48}>\text { PM *fuddza 'whale' } \\
\text { PR *udzura }{ }^{49}>\text { PM *uddza 'quail' }\end{array}$ \\
\hline
\end{tabular}

Observing the reflexes found in Yaeyama and Dunan, one finds that FA can be attested in one way or another in most of them, which should allow for a reconstruction of FAR-ed forms on the PS level (although the matter requires further specification and scrutiny). The same, however, not the case with FDR.

Flap deletion (FD) occurs in the PR contexts where $*_{r}$ was followed by $*_{i}$ or $* u$. In this environment, $*_{\mathrm{i}}$ and $*_{\mathrm{u}}$ merged into $\mathrm{PM} *^{*}$. Here, one can hypothesize that the PR unrounded realization of $* u$ after sibilants (as proposed by Thorpe 1983 and discussed in 3.2. and 3.4.) extended to all coronals, also to *r. This resulted in the *ri $\sim$ *ru realization of this sequence, which later developed as $*_{1}>*_{1}$ at the PM stage.

In modern Miyakoan regiolects, *1 developed further in accordance with the patterns described in 3.1. and 3.6.

The pattern of evolution of FD in Miyakoan can be presented as follows:

$\mathrm{PR} *$ tori $>$ PS *turi $>$ PM *tur $>*$ tuๆ 'bird'

44 There is a number of examples of PM vocabulary with an underlying * pur sequence (tentative PR *pur-i > PM *fuๆ 'to rain, to precipitate', Thorpe's *puru > PM *fu^ 'old'), but they do not produce the expected FAR outcome. Perhaps, contrary to one's expectations, *pur simply was not one of the FAR conditions, surprising as it may seem with the conditioning asymmetry it would produce. The reason for this asymmetry might be that the onset of $* \mathrm{pu}>* \mathrm{fu}$ fricativization was later than of its $* \mathrm{ku}>*$ fu counterpart, and the $* \mathrm{pu}>*_{\mathrm{fu}}$ change occurred too late to make the *pur string an eligible FAR conditioning.

45 Tentative reconstruction by the author.

${ }^{46}$ No examples of PR vocabulary with the sequence *tir have so far been found.

47 Tentative reconstruction by the author, PS *katsira. Thorpe 1983 reconstructs PR *kazura.

48 Thorpe's $<\mathrm{G}>$ indicates a velar stop of an unspecified voicing. Even though the Miyakoan reflexes clearly imply a voiceless origin of the initial consonant, Thorpe attributes it to these forms being Japanese loans. I will refrain from passing a judgment on this matter at this point of my research, although I do doubt if a Sakishima loan of this specific item could be dated enough to precede the activation of FAR. Bentley 2008 reconstructs PS *kuzira.

49 Tentative reconstruction by the author, PS *udzira. 
$\mathrm{PR} *$ joru $^{50}>\mathrm{PS} *$ juri $>\mathrm{PM} *$ jur $>$ *ju१ 'night'

Although FDR can be confirmed for many Northern Ryukyuan regiolects and even for mainland Kyushu dialects such as Kagoshima (Hirayama et al. 1967; Miyara 1980), at least for the *ri context, it is curiously and consistently absent from Yaeyama, Miyakoan's closest relative. It is also inconsistent in Dunan (cf. PR *kusori > DN ts'uri for PM *fusul 'medicine'). This must be interpreted as an indication that FD occurred throughout the south-western area of the Japonic family independently (at least independently of their genetic proximity, since an areal diffusion of this feature might have been a factor here). On the other hand, as the evidence of a pre-close-vowel * $r$ in modern Miyakoan regiolects is scarce ${ }^{51}$, FD can be assumed to have mostly been completed at the PM stage.

Since the application of FDR to PR *ri strings relies on the distinction between PR $*_{i}$ and $*_{\mathrm{e}}$, it follows to observe that the PM reflexes of $*_{\mathrm{i}}$ and $*_{\mathrm{e}}$ had to be distinct phonemes at the time FDR set in. FD was likely a relatively late change that occurred only after the $*_{\mathrm{i}}>*_{1}$ and $*_{\mathrm{e}}>*_{\mathrm{i}}$ shifts had been complete.

Table 10: FDR, or PR close vowels following * $\mathrm{r}$ in PM

\begin{tabular}{l|l}
\hline \multicolumn{1}{c|}{ PR environment } & \multicolumn{1}{|c}{ Example } \\
\hline$*$ ri & PR *tori $>$ PM *tu 'bird' \\
\hline$*$ ru & PR *joru $>$ PM *ju 'night' \\
\hline
\end{tabular}

The identification of FAD and FAR along with their relative chronology may have significant implications for Proto-Ryukyuan and maybe even Proto-Japonic reconstructions of the affected items. This idea has been elaborated upon in the section 4.

\subsection{Regressive assimilation of initial $* i$ and $* u$}

Regressive assimilation of word-initial PR close vowels is a convincing illustration of drag chains working in Miyakoan. If $\mathrm{PM} *_{1}^{*}$ or *u were followed by a nasal, they would completely assimilate with that nasal, producing a long consonant or a geminate in the process.

$\mathrm{i}, \mathrm{u}>\mathrm{m}, \mathrm{n} / \# \_\mathrm{m}, \mathrm{n}$

So far, PM items reconstructible for PR with an initial *im or *un have not been found, which makes the vocabulary with initial *in and *um the only evidence avail-

\footnotetext{
${ }^{50}$ Thorpe's *jUru; here and thereafter it has been decided to tentatively rewrite Thorpe's *jU reconstructions as $*$ jo.

${ }^{51}$ The exception here being examples of verbal morphology in the Ōgami regiolect as presented in Pellard 2009:318. Verbs with stems ending in -r may have been more resistant to FD due to the fact that FD would occur here across the morpheme boundary.
} 
$a^{5 b l}{ }^{52}$. If, however, such items are discovered at some point, they are expected to conform to this assimilation rule.

Table 11: Assimilation of initial close vowels with nasals

\begin{tabular}{|c|c|}
\hline PR environment & Examples \\
\hline *\#in & 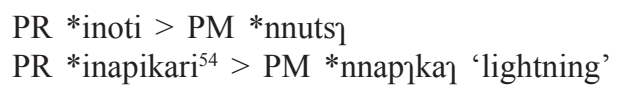 \\
\hline *\#um & $\begin{array}{l}\text { PR *umu }{ }^{55}>\text { PM *mm 'sweet potato' } \\
\text { PR *umarer-i }{ }^{56}>\text { PM *mmari 'to be born' }\end{array}$ \\
\hline
\end{tabular}

The following example from the MHN data illustrates the stages of this particular push chain. For the item meaning 'eel', which is assessed to have been an older loan of Japanese unagi $^{56}$, the following regional forms are given: unagz or mnagz (Hirara) and $\breve{u n a d z\rceil}$ (Sawada and Sarahama). These forms imply that if an initial /u/ was followed by a nasal, it would first be shortened, and then assimilated (in this case only partially, $/ \mathrm{mn}$ ) by becoming a nasal itself. A similar course should have taken place with inherited vocabulary at the PM stage.

Regressive assimilation of initial close vowels has been carried even further in Ikema and, in some instances, also in Tarama, extending the assimilation process also to a number of consonant-initial strings including PM *fu and *ts. Compare PM *fumu $>$ Ikema $m m u$ vs. Hirara $f m u$ 'cloud', *fum > Ikema $m m$ vs. Hirara fum 'to draw water', *tspnu $>$ Ikema $n п u$ vs. Hirara tspnu 'horn', or *tşna > Ikema nna, Hirara tspna 'rope'. This resembles a similar change that occurred in Dunan involving PS sequences such as *tsim, *tsin, *kim, or *kin: *tino > nnun 'horn', *kino: > nnu 'yesterday'.

About partial assimilation of PM $*_{i}$ with non-nasals, cf. 3.6.

Another assimilative phenomenon apparently triggered by the mid-vowel chain shifts was completed in modern Miyakoan regiolects (briefly indicated also in Thorpe 1983: 41 as a "probably relatively recent" change), meaning only after PM had split. This phenomenon concerns the regressive assimilation of the initial PM *1 with the following PR/ PS (not necessarily PM, cf. below) $* \mathrm{j}$ and *r. Although this development exceeds the PM

${ }^{52}$ If sequences $* \mathrm{im}$ and *un were indeed absent in PR, it can be explained by universal articulatory constraints: a transition from a close front vowel to a bilabial consonant posits some articulatory effort, and so does a transition from a close back vowel to a coronal consonant. Also, Thorpe 1983 gives one item with initial *im, *ime 'dream' (PM *imi). If this paper's hypothesis of regressive assimilation is correct, PR 'dream' should rather be reconstructed as *eme.

${ }^{53}$ Tentative reconstruction by the author.

${ }^{54}$ Tentative reconstruction by the author, PS *umu; Thorpe's *umo would have produced Miyakoan Xmmu.

${ }^{55}$ Tentative reconstruction by the author, PS *umarer-i.

${ }^{56}$ Thorpe 1983: 37 does reconstruct *Unagi for PR, but he only gives two modern Ryukyuan forms from those on which this reconstruction was based, and he indicates these two as aberrant. Naturally, there is still the possibility that the regional forms mentioned above are in fact inherited, which would invalidate the regressively assimilated reconstructions for PM - this, however, does not seem likely at this point. 
stage, it has been decided to incorporate it into the present paper because of its valuable illustration of how chain shifts work in Miyakoan to ensure maintaining the contrast between PR $*_{\mathrm{i}}$ and $*_{\mathrm{e}}$.

In order for this change to be explained, PS level turns out at least as relevant as PR, and therefore its reconstructions have also been included in Table 12.

In certain items, PR initial *uj (Thorpe's * $\mathrm{Uj}$ ) has developed into $*_{\mathrm{ij}}$ in PS, and then into ${ }^{*} \mathrm{z}$ in PM. This change could have been irregular, but to specify that would require further investigation which exceeds the scope of this paper.

Miyakoan examples have been represented by the Hirara regiolect only in order to narrow down the content of the table. In Hirara, fricative characteristics of *1 caused the fricativization of the following $* \mathrm{j}$ or $* \mathrm{r}$, eventually turning the initial sequence into geminated $/ \mathrm{zz} /$.

Table 12: Assimilation of initial ${ }^{*} 1$ in Hirara before PS $*_{\mathrm{j}}$ and $*_{\mathrm{r}}$

\begin{tabular}{l|c|c|c|c}
\hline \multicolumn{1}{c|}{ Meaning } & PR & PS & PM & Hirara \\
\hline 'father' & uja $^{58}$ & ija & qza & zza \\
\hline 'fish' & ijo $^{59}$ & iju & qzu & zzu \\
\hline 'placenta' & ija $^{60}$ & ija & qza & zza \\
\hline 'sickle' & irana & irara $^{61}$ & qzara & zzara \\
\hline 'inserting' & ire $^{62}$ & iri & 1zi & zzi \\
\hline
\end{tabular}

Starting from the PS stage, this push chain development can be therefore illustrated as follows:

$$
\begin{aligned}
& \text { ij }>1 j>1 z>z Z \\
& \text { ir }>1 r>1 z>z Z
\end{aligned}
$$

\section{Conclusions}

The following table sums up the disambiguating chain-shift strategies that have been explored in this paper. The arrow mark pointing from Stage 1 to Stage 2 columns indicates that the changes of Stage 1 activated or led to the changes of Stage 2. Obviously, the changes of Stage 1 are assumed here to have been the first to start, but just as obviously, they cannot have been completed before the changes of Stage 2 were set off. In other words, the table is supposed to represent Stage 1 and 2 changes that at some point were happening simultaneously.

\footnotetext{
57 Thorpe's Uja.

58 Thorpe's ijU.

59 Tentative reconstruction by the author.

60 Apparently, PS underwent here a sporadic distant assimilation of $*_{\mathrm{n}}>*_{\mathrm{r}}$ : *irana $>*_{\text {irara }}$

61 Tentative reconstruction by the author.
} 
Like in Table 12, Hirara regiolect has been chosen to represent what happened further to the reflexes of interest at the post-PM stage.

Table 13: Chain shifts involving mid- and close vowels in Miyakoan

\begin{tabular}{|c|c|c|c|}
\hline PR environments & Stage $1 \rightarrow$ & Stage 2 & $\begin{array}{c}\text { Stage } 3 \text { outcomes } \\
\text { (Hirara) }\end{array}$ \\
\hline $\begin{array}{l}\text { *pe, *be, *ke, *ge; } \\
\text { *pi, *bi, *ki, *gi }\end{array}$ & $\begin{array}{l}*_{\text {pe, }} *_{\text {be, }} *_{\text {ke, }} *_{\text {ge }} \\
>*_{\text {pi, }} * \text { bi, *ki, *gi }\end{array}$ & $\begin{array}{l}* \mathrm{pi},{ }^{*} \mathrm{bi},{ }^{*} \mathrm{ki}, *_{\mathrm{gi}} \\
>*_{\mathrm{p}}, *^{\mathrm{b}_{1},}, \mathrm{k}_{\mathrm{l}}, *_{\mathrm{g}}\end{array}$ & $\begin{array}{l}\text { pi, bi, ki, gi; } \\
\text { ps, bz, ks, gz }\end{array}$ \\
\hline 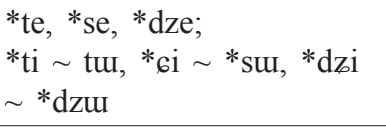 & $\begin{array}{l}*_{\mathrm{te}} *_{\mathrm{se}} *_{\mathrm{dze}} \\
>*_{\mathrm{ti}} *_{6 \mathrm{i}} *_{\mathrm{d}} \mathrm{di}\end{array}$ & 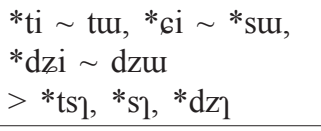 & $\begin{array}{l}\text { ti, si, dzi; } \\
\text { ts1, s1, dzl }\end{array}$ \\
\hline $\begin{array}{l}* \mathrm{po},{ }^{*} \mathrm{bo},{ }^{*} \mathrm{ko},{ }^{*} \mathrm{go} \\
{ }^{*} \mathrm{pu},{ }^{*} \mathrm{bu},{ }^{*} \mathrm{ku},{ }^{*} \mathrm{gu}\end{array}$ & $\begin{array}{l}* \text { po, *bo, *ko, *go } \\
>*^{*} \text { pu, *bu, *ku, *gu }\end{array}$ & $\begin{array}{l}* \mathrm{pu}, * \mathrm{bu}, * \mathrm{ku},{ }^{*} \mathrm{gu} \\
>*^{\mathrm{fu}}, * \mathrm{vu}, * \mathrm{fu}, *_{\mathrm{vu}}\end{array}$ & $\begin{array}{l}\mathrm{pu}, \mathrm{bu}, \mathrm{ku}, \mathrm{gu} ; \\
\mathrm{f}(\mathrm{u}), \mathrm{v}, \mathrm{f}(\mathrm{u}), \mathrm{v}\end{array}$ \\
\hline $\begin{array}{l}* \text { to, } *_{\text {so, }} * \text { dzo; } \\
* \text { tu } \sim \text { tur, } * \text { su } \sim *_{\text {sur }} * \text { dzu } \\
* \text { dzu }\end{array}$ & $\begin{array}{l}* \text { to, } *_{\text {so, }} * \text { dzo } \\
>* \text { tu, } *_{\text {su, }} * \text { dzu }\end{array}$ & $\begin{array}{l}* \text { tu } \sim \text { tur, } * \text { su } \sim *_{\text {sul }} \\
* \mathrm{dzu} \sim \mathrm{dzu} \\
>*_{\mathrm{ts}},{ }^{*}{ }_{\mathrm{s}},{ }^{*} \mathrm{dz} 1\end{array}$ & $\begin{array}{l}\text { tu, su, } * d \mathrm{du} \\
\text { ts1, s1, } * \mathrm{dz} 1\end{array}$ \\
\hline $\begin{array}{l}*_{\text {me, }}^{*}{ }^{*} \text { mo, *ne, *no; } \\
*_{\text {mi, }}^{*} \text { mu, *ni, *nu }\end{array}$ & 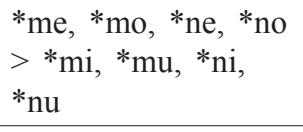 & $\begin{array}{l}* \mathrm{mi}, * \mathrm{mu},{ }^{*} \mathrm{ni}, * \mathrm{nu} \\
>*_{\mathrm{m}},{ }^{*} \mathrm{~m},{ }^{*} \mathrm{n},{ }^{*} \mathrm{n}\end{array}$ & $\begin{array}{l}\mathrm{mi}, \mathrm{mu}, \mathrm{ni}, \mathrm{nu} \\
\mathrm{m}, \mathrm{m}, \mathrm{n}, \mathrm{n}\end{array}$ \\
\hline $\begin{array}{l}* \mathrm{Ve}, * \# \mathrm{e}, * \mathrm{Vo}, * \# \mathrm{o} \\
* \mathrm{Vi}, * \# \mathrm{i}, * \mathrm{Vu}^{63}, * \# \mathrm{u}\end{array}$ & $\begin{array}{l}* \mathrm{Ve}, * \# \mathrm{e}, * \mathrm{Vo}, * \# \mathrm{o} \\
>* \mathrm{Vi}, * \# \mathrm{i}, * \mathrm{Vu}, * \# \mathrm{u}^{64}\end{array}$ & $\begin{array}{l}* \mathrm{Vi}, * \# \mathrm{i}, * \mathrm{Vu}, * \# \mathrm{u}> \\
* \mathrm{~V},{ }^{* \# 1}, * \mathrm{Vu}, * \# \mathrm{u}\end{array}$ & $\begin{array}{l}\mathrm{Vi}, \# \mathrm{i}, \mathrm{Vu}, \# \mathrm{u} ; \\
\mathrm{Vz}, \# \mathrm{z}, \mathrm{Vu}, \# \mathrm{u} / \mathrm{v}\end{array}$ \\
\hline $\begin{array}{l}\text { *bor, *kor; } \\
\text { *bur, *kur }\end{array}$ & $\begin{array}{l}\text { *bor, *kor } \\
>\text { *bur, *kur }\end{array}$ & $\begin{array}{l}* \text { bur, *kur } \\
>* \text { vur, *fur } \\
>* \text { vuv, *fuf }\end{array}$ & $\begin{array}{l}\text { bur, kur; } \\
\text { vv, ff }\end{array}$ \\
\hline $\begin{array}{l}*_{\text {ser, }} *_{\text {sor, }} * \text { dzor, *ter, *tor } \\
*_{\text {cir, }}^{*} \text { sur, *dzur, *tir, *tur }\end{array}$ & $\begin{array}{l}*_{\text {ser, }} *_{\text {sor, }} * \text { dzor, } \\
*_{\text {ter, }} * \text { tor } \\
>*_{\text {cir, }} \text { *sur, *dzur, } \\
*_{\text {tir, }} * \text { tur }\end{array}$ & 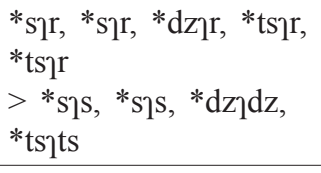 & $\begin{array}{l}\text { cir, sur, *dzur, tir, } \\
\text { tur; } \\
\text { ss, ss, ddz, tts }{ }^{66}\end{array}$ \\
\hline $\begin{array}{l}\text { *re, *ro; } \\
\text { *ri, *ru } \sim \text { ruI }\end{array}$ & $\begin{array}{l}* \text { re, } * \text { ro } \\
>* \text { ri, *ru }\end{array}$ & $\begin{array}{l}*_{\mathrm{ri}}, * \mathrm{ru} \sim \mathrm{ruu} \\
>*_{1}, *_{1}\end{array}$ & $\begin{array}{l}\text { ri, ru; } \\
\mathrm{z}, \mathrm{z}\end{array}$ \\
\hline $\begin{array}{l}*_{\text {en, }} *_{\mathrm{om}} \\
*_{\text {in, }} *_{\text {um }}\end{array}$ & $\begin{array}{l}* \text { en, } *_{\mathrm{om}} \\
>*_{\mathrm{in},}{ }^{*} \mathrm{um}\end{array}$ & $\begin{array}{l}*_{\mathrm{in},}^{*} *_{\mathrm{um}} \\
>*_{\mathrm{nn},}^{*}{ }^{\mathrm{mm}}\end{array}$ & $\begin{array}{l}\text { in, um; } \\
\text { nn, mm }\end{array}$ \\
\hline $\begin{array}{l}* \text { er, *ej; } \\
*_{\text {ir, }} * \text { ij }(<* \# \text { uj })\end{array}$ & $\begin{array}{l}*_{\mathrm{er}} *_{\mathrm{ej}} \\
>*_{\mathrm{ir},} *_{\mathrm{ij}}\end{array}$ & $\begin{array}{l}*_{\mathrm{ir},} *_{\mathrm{ij}} \\
>*^{*} \mathrm{r},{ }^{*} \mathrm{jj}\end{array}$ & $\begin{array}{l}* \mathrm{ir}, * \mathrm{ij} \\
\mathrm{zz}, \mathrm{zz}\end{array}$ \\
\hline
\end{tabular}

${ }^{62}$ As mentioned in 3.6., the correspondences with this $\mathrm{PR} * \mathrm{Vu}$ string are in fact more complex. For the sake of simplicity, they have not been incorporated in this chart.

${ }^{63}$ Should one choose to account for the standalone $* \mathrm{u} / *^{*} \mathrm{o}$ distinction as hypothetically witnessed in pairs such as $v d a$ 'thick' vs. $u d i$ 'arm' etc. (cf. a footnote to Table 8), there should be a distinction in reconstructions of Stage $1 * \# \mathrm{o}>* \# \mathrm{u}$ and Stage $2 * \# \mathrm{u}>* \# \mathrm{u}$. Some propositions that require a further consideration involve *\#o $>\#^{*} v$ and \#*u $>$ \#*u.

${ }^{64}$ For a more detailed account of the stages of this change, cf. 3.7. and Table 9.

${ }^{65}$ For a more detailed account of the stages of this change, cf. 3.7. and Table 9. 
One striking feature of these changes is their symmetry for the both PR close vowels. This instance is represented on several levels; most generally, apart from the onsetless positions and post-PM regressive assimilation change presented in Table 12 (which in the end also involves PR ${ }^{*} \mathrm{u}$ in a number of sporadic instances, cf. *uja $\left.>z z a\right)$, there are hardly any changes to $\mathrm{PR} *_{\mathrm{i}}$ that would not be accompanied by a parallel change in exactly the same environment for $* u$, and vice versa. Although the relative chronology of these changes may have differed (as observed for FDR in 3.7.), these disambiguating chain shifts in general have served to maintain not only the relevant phonological distinctions, but also an overall balance of the Miyakoan sound system.

This can be viewed as a manifestation of the system's self-regulating drive for maintaining its structure even in the face of a major phonological change. Although the specific variables constituting the system and its contrasts may change (e.g. PR $*_{\mathrm{u}}$ and $*_{\mathrm{o}}$ after stops had merged by PM while PR $*_{\mathrm{i}}$ and $*_{\mathrm{e}}$ in the same context remained distinct vowels), the contrasts are maintained and affect all the pertinent sounds in the system (e.g. all stops after the $P R * u$ underwent fricativization while all stops after the $\mathrm{PR} *_{\mathrm{o}}$ remained unchanged; PR $*_{\mathrm{i}}$ after stops underwent fricativization and $\mathrm{PR} *$ e remained as a new close front vowel). Thus, a single but systemically crucial contrast between close and mid vowels has been transferred to other parts of the system, reappearing as a contrast between stops and fricatives, "regular" and "apical" vowels, vowels and fricatives, flap and zero, etc. This observation aligns with Martinet's 1952: 18 view that "if a change [involving a functionally loaded distinction] takes place, it is less likely to result in a merger than if the opposition were limited to a single pair".

An interesting question is why the PM push chains, in striving to disambiguate PR $*_{i}$ and $* u$ from the rising mid-vowels, occasionally ended up merging PR $*_{i}$ and ${ }^{*} u$, such as in the post-coronal contexts. This matter should be addressed in the course of a further PM/PS study.

Among the key implications resulting from the present study one can include consistent reconstructions of PM close vowels as PR mid-vowels, save for the clearly evidenced exceptions where $\mathrm{PR} * \mathrm{i}$ or $* \mathrm{u}$ were retained. Unless there is data from other PR daughter languages to the contrary, one can assume that as a rule, PR close vowels have not been straightforwardly maintained in PM. In other words, one should generally be wary of reconstructing PR $*_{\mathrm{i}}$ or $*_{\mathrm{u}}$ for $\mathrm{PM} * \mathrm{i}$ or $* \mathrm{u}$.

One consequence of the above will be proposing PR reconstructions which may not have been established yet, or adding clarification to existing reconstructions that cause controversies. As an example of such affected reconstructions one can give PM words with an initial ${ }^{*} \mathrm{vv}$, such as ${ }^{*} \mathrm{vv}$ ' 'to sell'. Due to a paucity of PR vocabulary with an unambiguous initial *ur, for the time being it is impossible to determine if this *ur could produce an outcome identical to FAR sequences *bur and *gur. Consequently, one is left unable to pass a confident judgment if the PR word for 'sell' should be reconstructed as *ur-i or *bur-i.

If, however, one scrutinizes Miyakoan verbal morphology, it turns out that $*_{\mathrm{r}}$ in the FAR-affected verbs underwent assimilation in all inflectional forms and not just finitely; 
cf. the following Nakachi examples: *nebur-i ${ }^{66}>$ niv 'to sleep', nivvan 'not to sleep', nivvi 'sleep (imperative)'; *tagur-i > tav 'to reel', tavvan 'not to reel', tavvi 'reel (imperative)'. This is in contrast with verbs affected by FDR, which stems retain *r unless followed by the PR *i: *ar-i > az 'to be', aran 'not to be', ari 'be (imperative); *bodor-i $>$ buduz 'to dance', buduran 'not to dance', buduri 'dance (imperative)'. Nakachi $v v$ 'to sell' inflects according to the former pattern: vvan 'not to sell', vvi 'sell (imperative)'. Based on the knowledge that FAR was an earlier change than FDR, one concludes that whether it reflects PR *bur or *ur, *vVl must have undergone a kind of FA and that by the time FDR was activated in PM, *vvl had already had no flap to delete.

There are thus two conceivable answers regarding the PR ancestor form of PM *VV]. One postulates that *VV1 reflects a "regular" FA with an initial bilabial stop that has been

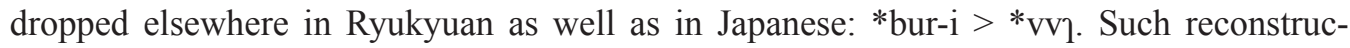
tion has been proposed in Whitman 1985: 17 as well as Vovin 2010: 37-38. Another claims that *\#ur sequences with a standalone $* u$ did in fact undergo a mutual assimilation resembling that of FAR, evolving as $*_{\mathrm{ur}-\mathrm{i}}>*_{\mathrm{vr}}>*_{\mathrm{vv}}$. Apart from Thorpe, this reconstruction is supported by Pellard (2009: 354, 2017: 10-11). The question which of the two is more likely is rather complex and it will not be addressed here. In the light of the above evidence, however, one can at least posit an unambiguous initial $*_{u} \mathrm{in}$ this reconstruction, narrowing down Thorpe's *Uri to *ur-i. This assumption is further endorsed by the vocabulary which is thought to unequivocally reflect PR *o as PM *u: *or-i $>$ *u1 'to weave', *orer-i $>$ *uri 'to descend'.

Another implication of the chain shift approach to studying sound change in Miyakoan is that it can help distinguish between inherited lexicon and phonologically adjusted Japanese loans, such as Hirara kuni 'land, village' from Japanese kuni 'land' (expected Xfun) or fukuro from Japanese fukuro (expected Xfuffu). Likewise, by helping establish the basic rules allowing for the recognition of $*_{i}$ and $*_{u}$ reflexes in various non-trivial circumstances, the push chain concept as adopted in this paper sets these reflexes apart from irregular changes that require additional explanation, such as a different proto-sound reconstruction (cf. the 'flesh' reconstructions in 3.6.).

Looking broadly at Miyakoan sound system in its entirety, this push chain concept also offers an explanation to the unusual consonantal quality (the presence of a range of permitted consonant clusters and moraic consonants) which Miyakoan is known for in comparison with other Japonic regiolects. With changes such as $*_{\mathrm{i}}>*_{1}>\mathrm{z}$ or $*_{\mathrm{u}}>\mathrm{v}$, it is safe to assume that most, if not all, consonant clusters and moraic consonants in Miyakoan are a direct result of the original PR close vowels escaping homophony with the original PR mid-vowels.

Finally, chain shifts caused by the PR mid-vowel raising appear to have been at work in a large number of other Ryukyuan daughter languages, although they were obviously realized through different disambiguation techniques. Chain shifts can be thus considered a valid concept when examining one of the most instrumental and functionally loaded changes that have occurred since PR.

${ }^{66}$ All PR and PM reconstructions in the following two paragraphs, unless specified otherwise, are by the author. 


\section{Abbreviations}

DN - Dunan; FA - flap assimilation; FAR - flap assimilation rule; FD - flap deletion; FDR - flap deletion rule; JP - Japanese; MHN - Miyako Hōgen Nōto (Nevskiy 2005); PM - Proto-Miyakoan; PR - Proto-Ryukyuan; PS - Proto-Sakishima; RK - Ryukyuan.

\section{References}

Aoi, Hayato \& Yuto, Niinaga. 2013. The central high vowels in Ryukyuan languages: a comparative palatographic study of Yuwan Amami and Tarama Miyako. In: Masayoshi, Shibatani (ed.), International Journal of Okinawan Studies 4-1. Special Issue on Ryukyuan Languages, 3-11.

Bentley, John R. 2008. A linguistic history of the forgotten islands: a reconstruction of the proto-language of the Southern Ryūkyūs. Folkestone: Global Oriental.

Campbell, Lyle. 1998. Historical linguistics: an introduction. Cambridge, Massachusetts: The MIT Press.

Hirayama Teruo, in collaboration with Ichirō Ōshima and Masachie Nakamoto. 1967. Ryūkyū Sakishima hōgen-no sōgōteki kenkyū [General research of Sakishima Ryukyuan dialects]. Tokyo: Meiji Shoin. /// 平山 輝男『琉球先島方言の総合的研究』大島一郎、中本正智共著 東京都・明治書院。

Hock, Hans Heinrich. 1991. Principles of historical linguistics. Second revised and updated edition. Berlin, New York: De Gruyter Mouton.

Iha, Fuyū \& Hashimoto, Shinkichi. 1934. Ryūkyūgo gaikan [An outline of the Ryukyuan language]. Hōgen 10, vol. 4, pp. 1-12. /// 伊波普珻 橋本新吉「琉球語概観」『方言』第10号第4巻。

Ikema, Nae. 2003. Yonagunigo (dunanmunui) jiten [Dictionary of the Dunan language]. Yonaguni: private publication.

Iwakura, Ichirō. 1934. Kikaigo on'in gaisetsu [basic phonology of the language of Kikai island]. Hōgen 10, vol. 4, pp. 13-23. /// 岩倉市郎「喜界語音韻概説」『方言』第10号第4巻。

Jarosz, Aleksandra. 2015. Nikolay Nevskiy's Miyakoan Dictionary: reconstruction from the manuscript and its ethnolinguistic analysis. Poznan: Chair of Oriental Studies, Faculty of Modern Languages and Literature. (Ph.D. dissertation.)

Kajiku Shin'ichi (supervisor), Seiki Inafuku (author-editor). 1992. Igaku Okinawago jiten [A dictionary of medical Okinawan language]. Ginowan: Roman Shobō. /// 加治工真市監修、稲福盛輝編著者 『医学 沖縄語辞典』 宜野湾市・ロマン書房。

Karimata, Shigehisa. 2005. Okinawa Miyako Hirara hōgen-no fonēmu. Ryūkyū Daigaku Hōbungakubu, Nihon Tōyō Bunka Ronshū 11 (March), 67-113. I// かりまたしげひさ「沖縄宮古平良方言のフォネーム」琉 球大学法文学部, 日本東洋文化論集 11 。

Kibe, Nobuko (ed.). 2012. General study for research and conservation of endangered languages in Japan. Research report on Miyako Ryukyuan. NINJAL Collaborative Research Projects Reports 12-02. Tokyo: National Institute for Japanese Language and Linguistics. // 木部暢子編『消滅危機方言の調査・保存 のための総合的研究 南琉球宮古方言調査報告書』東京都・国立国語研究所。

Labov, William. 1994. Principles of linguistic change. Vol. 1: Internal factors. Oxford, Cambridge: Blackwell Publishers.

Martinet, André. 1952. Function, structure, and sound change. Word 1-8. 1-32.

Miyara, Tōsō. 1980 [1926]. Miyara Tōsō zenshū 7 [The complete works of Tōsō Miyara, vol. 7]. Tokyo: Daiichi Shobō. // 宮良當荘『宮良當荘全集7』東京都・第一書房。

Nakamoto, Masachie. 1976. Ryūkyū hōgen on'in-no kenkyū [Phonological research of Ryukyuan dialects]. Tokyo: Hosei Daigaku Shuppankyoku. /// 中本正智『琉球方言音韻の研究』 東京都・法政大学出 版局。Nevskiy, Nikolay A. 2005. Miyako hōgen nōto: fukushabon [Notes on Miyakoan dialects: facsimile edition], vols. 1-2. Hirara: Okinawa-ken Hirara-shi Kyōiku Iinkai. //I ニコライ・A・ネフスキー 『 宮古方言ノート 複写本』上・下 平良市・沖縄県平良市教育委員会。

Nakasone, Seizen. 1934. Kunigami hōgen-no on'in [Phonology of the Kunigami dialect]. Hōgen 10, vol. 4, Ppp. 37-48. /// 仲宗根政善「國頭方言の音韻」『方言』第10号第4巻。 
Nakasone, Seizen. 1983. Okinawa Nakijin hōgen jiten [A dictionary of Nakijin dialect in Okinawa]. Tokyo: Kadokawa Shoten. /// 仲宗根政善『沖縄今帰仁方言辞典』東京都・角川書店。

Nakasone, Seizen \& Ōshiro, Ken \& Yabiku, Hiroshi \& Narita, Yoshimitsu \& Uchima, Chokujin. 1968. Miyako hōgen-no kenkyū [A study of Miyakoan dialects]. Ryūkyū Daigaku Okinawa Bunka Kenkyüjo Miyako shotō gakujutsu chōsa kenkyū hōkokusho. Gengo/bungaku-hen [A report of academic studies of the Miyako islands, the volume on language and literature], 1-62. Naha: Ryūkyū Daigaku Okinawa Bunka Kenkyūjo. /// 仲宗根政善、大城健、屋比久浩、成田義光、内間直仁「宮古方言の研究」琉球大学沖 縄文化研究所『宮古諸島学術調査研究報告書』那覇市・琉球大学沖縄文化研究所。

Nakama, Mitsunari. 1992. Ryūkyū hōgen-no kosō [Old layers of Ryukyuan dialects]. Tokyo: Daiichi Shobō. /// 名嘉真三成『琉球方言の古層』 東京都・第一書房。

Nishioka, Satoshi. 2013. Okinawago gaisetsu [Outline of Okinawan language]. In: Okinawa Daigaku Chiiki Kenkyūjo (ed), Ryūkyū shogo-no fukkō [Restoration of Ryukyuan languages], 65-86. Tokyo: Fuyō Shobō. I/I 西岡敏『「沖縄語」概説』沖縄大学地域研究所編『琉球諸語の復興』東京都・芙蓉書房。

Pellard, Thomas. 2009. Ōgami - Éléments de description d'un parler du Sud des Ryūkyū [Ōgami: basic description of a language of the southern Ryukyus]. Paris: École des hautes études en sciences sociales. (Ph.D. thesis.)

Pellard, Thomas. 2010. Ōgami (Miyako Ryukyuan). In: Pellard, Thomas \& Michinori, Shimoji (eds.), An introduction to Ryukyuan languages, 113-166. Tokyo: Research Institute for Languages and Cultures of Asia and Africa, Tokyo University of Foreign Studies.

Pellard, Thomas. 2015. The linguistic archeology of the Ryukyu islands. In: Patrick, Heinrich \& Shinsho, Miyara \& Michinori, Shimoji (eds.), Handbook of the Ryukyuan languages: history, structure, and use, 13-37. Berlin, Boston: De Gruyter Mouton.

Pellard, Thomas. 2017. Ryukyuan and the reconstruction of proto-Japanese-Ryukyuan. To be published in: Bjarke Frellesvig, Satoshi Kinsui and John Whitman (eds.), Handbook of historical Japanese linguistics. https://www.academia.edu/s/a086a96bc9/ryukyuan-and-the-reconstruction-of-proto-japanese-ryukyuan. (Accessed 2018-01-04)

Pellard, Thomas \& Yūka, Hayashi. 2012. Miyako shohōgen-no on'in: taikei-to hikaku [Phonology of Miyakoan dialects: their systems and comparison]. In: Kibe 2012，13-52. ///ママ ペラール、林由華「宮古諸方 言の音韻：体系と比較」。

Shimoji, Kazuaki. 1979. Miyako-guntōgo jiten [A dictionary of the language of Miyako island group]. Naha: Shimoji Yoneko. /// 下地一秋『宮古群島語辞典』那覇市・下地米子。

Shimoji Kayoko. 2017. Taramafutsi jiten. Tarama hōgen kiso goi [A dictionary of Tarama-Miyakoan. Basic vocabulary of the Tarama dialect]. Tarama: Tarama-son Kyōiku Iinkai. /// 下地賀代子 『たらまふつ辞 典。多良間方言基礎語彙』多良間村・多良間村教育委員会。

Takahashi, Toshizō. 1991. Omorosōshi-no kokugogakuteki kenkyū [A Japanese linguistics study of the Omorosōshi song collection]. Tokyo: Musashino Shoin. /// 高橋俊三『おもろさうしの国語学的研 究』東京 : 武蔵野書院。

Thorpe, Maner Lawton. 1983. Ryūkyūan language history. Los Angeles: University of Southern California. (Ph.D. dissertation.)

Tomihama, Sadayoshi 2013. Miyako Irabu hōgen jiten [A dictionary of Irabu-Miyakoan]. Naha: Okinawa Taimusu-sha. /// 富浜 定吉『宮古伊良部方言辞典』那覇市・沖縄タイムス社。

Vovin, Alexander. 2010. Koreo-Japonica: a re-evaluation of a common genetic origin. Honolulu: University of Hawai'i Press and Center for Korean Studies, University of Hawai'i.

Whitman, John Bradford. 1985. The phonological basis for the comparison of Japanese and Korean. (Ph. D. dissertation.) 